\title{
交通環境負荷軽減の観点からみた一方通航型港湾の検討
}

\author{
井上欣三*・胡 志武** ・ 臼井英夫* ・広野康平*
}

\section{A Study on One-way through Port from the Viewpoint of Reduction of Environmental Stress for Ship}

\author{
Kinzo INOUE, Zhiwu HU, Hideo USUI and Kouhei HIRONO
}

\begin{abstract}
The significant feature of one-way through port is that turning manoeuvre is unnecessary either entering or leaving port. This can lead to the effective use of waters, the reduction of the number of tugboats and ship-handling difficulty.

The harbour design in Japan has entered a stage of creating artificial features by the reclamation. The berth arrangement of harbours is changing from jetty-type to straight-line type.

From such a standpoint, the authors have suggested the conversion of idea from the usual dead-end port to one-way through port. In the previous report, a series of ship-handling simulator experiments were conducted, and the advantage of one-way through port was verified from the viewpoint of reduction of manoeuvring difficulty.

In the present paper, we took up the problem of the route crossing between navigation ships in passage routes and the entering/leaving ships, and conducted marine traffic simulation to examine the desirable entering way in one-way through port from the viewpoint of reduction of Environmental Stress for ship (ESs). The Environmental Stress Model was applied to evaluate the manoeuvring difficulties arising from various encounters with other ships in the process of entering/leaving port.

For designing, managing and using one-way through port concretely, the conclusions obtained through this research gave us a guideline for the design of layout of route and berth in one-way through port, the settlement of design ship entering/leaving by one-way, and the management of the traffic density of passage routes.
\end{abstract}

Key words : marine traffic engineering, one-way through port, marine traffic simulation, environmental stress model, maximum allowable traffic volume

キーワード：海上交通工学, 一方通航型港湾, 海上交通流シミュレーション, 環境ストレスモデル, 限界交 通量

\section{1.はじめに}

一方通航型港湾とは、港湾に入口と出口を設けて、 一方の入口から入港した船はそのまま入船の姿勢で 着岸し、出港に際しては出船の姿勢から岸壁を離れ、 そのまま進行方向にある出口に向かう、という至っ
てシンプルなバースと航路の配置形態からなる港湾 とイメージすればよい。

このような一方通航型港湾における最大の特徵 は、入港または出港時いずれにおいても船を反転さ せる必要がない点である。このことは、バース前面 にターニングベースンを配置する必要がないので港

* 正 会 員 神戸商船大学（干658-0022 神戸市東灘区深江南町5-1-1）

**学生会員 神戸商船大学大学院（T658-0022 神戸市東灘区深江南町5-1-1） 
湾管理者にとっては水域の有効利用につながり、ま た、着離岸操船に必要なタグ支援を減少できるので 船主にとっては経済負担の軽減につながり、さらに、 操船者にとっても着離岸操船時の操縦負荷軽減につ ながる、というメリットを有する。

近年、港湾は、埋立て造成により人工の地形を創 造し思いどおり設計できる時代となり、また、水際 線を長く確保する櫛の歯型バースからバース後背面 積を広く確保する直線型バースへと、そのありよう が変化してきている。

このような観点から、著者らは、従来の袋小路型 港湾から一方通航型港湾への発想の転換を促してき たが、前報(1)では、ビジュアル操船シミュレー夕実 験を行って操縦負荷軽減の観点から一力通航型港湾 のメリットを検証した。本報告では、一方通航型港 湾における航路航行船舶と着離岸船舶とのルート交 錯の問題をとりあげ、海上交通流シミュレーション を導入して交通環境負荷軽減の観点から、一方通航 型港湾における望ましい入出港形態について検討を 行った。

\section{2. 海上交通流シミュレーション}

\section{1 海域条件の設定と入出港方式の分類}

シミュレーション海域は $13,000 \mathrm{~m} \times 7,000 \mathrm{~m} の$ 範 囲とし、Fig. 1 に示寸ように、その中央に長さ2,800 $\mathrm{m} 、$ 幅 $2,700 \mathrm{~m}$ 直線バース式の人工島を配置し、こ の人工島を挟んで両側に幅 $600 \mathrm{~m}$ 、長さ $13,000 \mathrm{~m}$ の 対面通航航路を配置した。

Fig. 1 をみてわかるように、このような一方通航 型港湾においては、船舶のバースへの大出港方式は、 大きくは、航路筋に直交して配置されたバース（以 後、直交バースという）に着離岸する場合と、航路 筋に沿って平行に配置されたバース (以後、平行バー スという）に着離岸する場合の、2 種類に分けられ る。

さらに、直交バースへの着離岸の場合は、どちら から進入するかによって【時計回り一方通航】と【反 時計回り一方通航】に、平行バースへの着離岸の場 合は、どちらの舷を接岸するかによって【右舷付け 一方通航】と【左舷付け一方通航】に分類できる。

これら 4 種類の一方通航の方式は、それぞれ、入 出港時に航路航行船舶とどのようなルート交錯が生 じるかによって得失差がある。【時計回り一方通航】 では、入港航路からのスムーズな離脱、出港航路へ のスムーズな合流が期待できる。時計回り一方通 航】では、入出港時に対向レーンの横断を余儀なく される。【右舷付け一方通航】では、同様に、入港航

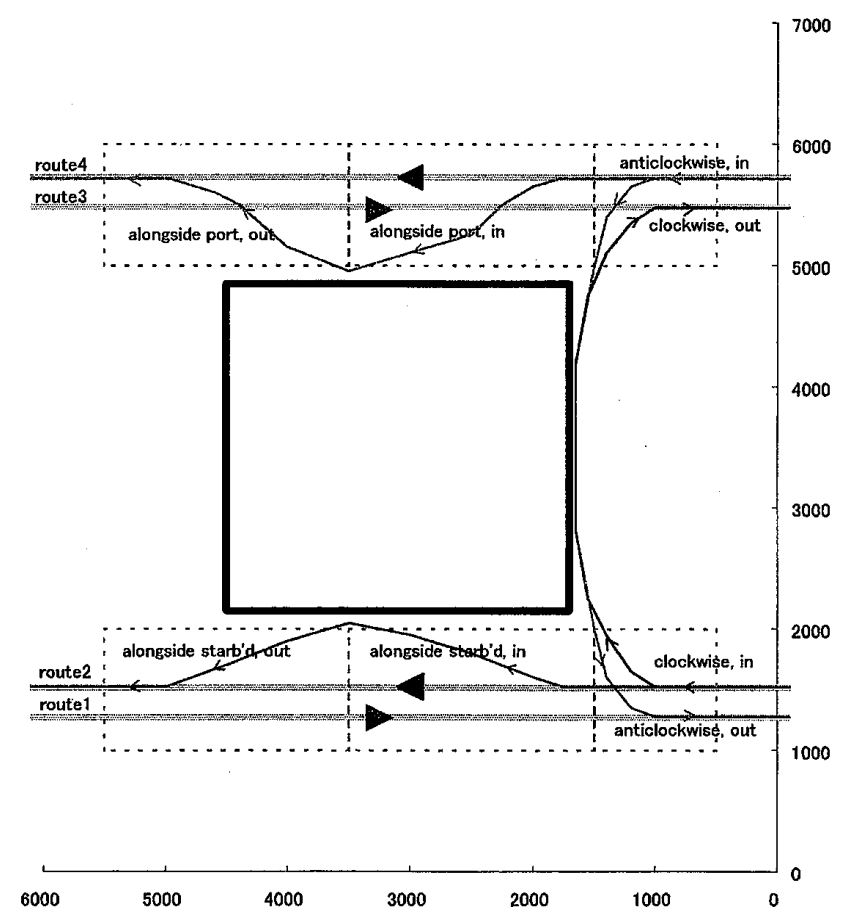

Fig. 1. Simulation schematic diagram

Table 1. Ship type composition

\begin{tabular}{|c|c|c|c|}
\hline Ship type & $\begin{array}{c}\text { Mean LOA } \\
(\mathrm{m})\end{array}$ & $\begin{array}{c}\text { Standard deviation } \\
(\mathrm{m})\end{array}$ & $\begin{array}{c}\text { Composition } \\
\%\end{array}$ \\
\hline Less than 1,000GT & 40 & 12.5 & 80 \\
\hline 1,000GT 10,000GT & 130 & 10 & 10 \\
\hline Beyond 10,000GT & 240 & 22.5 & 10 \\
\hline
\end{tabular}

路からのスムーズな離脱、出港航路へのスムーズな 合流が期待でき、【左舷付け一方通航】では、入出港 時に対向レーンの横断を余儀なくされる。

\section{2 航路交通流の発生}

交通流シミュレーションを実施するに際し、船舶 航行実態調查 ${ }^{(2)}$ を行って得られた神戸港第 3 航路 における早朝ラッシュ時のデータを参考にし、以下 のような条件設定のもとで、対面通航航路に船舶を 発生させた。但し、曳押航船、作業船、漁船、レジャー ボートは省いた。

（1）船型については、実態調查結果から得られた データを大型、中型、小型に分類し、Table 1 に示すような平均船長と標準偏差として、正 規乱数を用いて発生船舶の大きさを決定し た。また、各船型の構成比率は大型船、中型 船はそれぞれ全体の $10 \%$ 、小型船は全体の $80 \%$ とした。

(2) 発生船舶の航行速力については、全船型とも 平均速力を 6.0 ノット、標準偏差を 0.75 ノット として、正規乱数を用いて速力を決定した。 
（3）船舶の発生位置については、設定した航路 (route 1 , route 2 , route 3 , route 4) に設 けた発生ゲートラインに抄いて正規分布する ものとした。発生位置の分布の平均值位置は 対面通航航路 (幅 $600 \mathrm{~m}$ ) の中央線からそれぞ れ航路幅の $20 \%(120 \mathrm{~m})$ 右に偏した位置とし た (3)。また。分布の標準偏差は50 mとした。

(4) 船舶の発生隻数については、4つの航路 (route 1 , route 2 , route 3 , route 4 ) とも 同じ条件とし、入出港ともに 1 時間あたり 9 隻を基準に、その1.5倍の13.5隻/時と 2 倍の 18 隻/時の 3 種類とした。

\section{3. 交通環境負荷の評価}

\section{1 環境ストレスモデルの適用 ${ }^{(4)}$}

一方通航型港湾における航路航行船舶と着離岸船 舶とのルート交錯に起因して課される交通環境負荷 に着目し、一方通航型港湾における望ましい入出港 方式について検討を行った。一方通航型港湾におけ る交通環境負荷軽減の効果は、直交バースへの【時 計回り一方通航】と【反時計回り一方通航】扮よび 平行バースへの【右舷付け一方通航】と【左舴付け 一方通航】を対象に検討を行った。

まず、ここでの一連の検討に評価指標として用い る環境ストレスモデルについて概説する。このモデ 儿は、自然条件、地形条件、施設条件、交通条件な ど操船者を取り巻く周辺条件が操船者の行動を制約 する場合、その時々刻々に操船者に課せられる負荷 の大きさを、行動制約に伴う操船困難感に基づいて 定量化しようとする評価モデルである。

与えられた条件下で操船者に課せられる負荷を 「環境ストレス」と呼ぶが、その負荷が自然条件、 地形条件、施設条件などの操船環境に起因するとき、 これを操船環境ストレス $\left(\mathrm{ES}_{\mathrm{L}} \mathrm{L}\right)$ 、他船との出会いに 伴う行動制約に起因するとき、これを交通環境ス卜 レス $\left(\mathrm{ES}_{\mathrm{s}}\right)$ という。また、地形が制約されるなかで 他船と出会うというように、これら 2 つの負荷が複 合するとき、それらを総合化した負荷を総合環境ス トレス $\left(\mathrm{ES}_{A}\right)$ と呼ぶ。

環境ストレスの指標值化の手順は以下の通りであ る。

（1）現針路を中心に $\pm 90^{\circ}$ の針路範囲を考える。

(2) 針路刻み 1 ごとに、衝突もしくは乗揚げに至 るまでの時間余裕を算出する。

（3）危険顕在化までの時間余裕を操船者が感じる 危険感に換算する。

（4）原針路を中心とした $90^{\circ}$ の針路範囲内で危
険感を総計し、その合計值をその瞬間のスト レス值とする。

この環境ストレス值は、0から 1,000 までの值の範 囲で表現され、ES值が0から500未満までを[Negligible]、ES值500以上加 750未満を[Marginal]、ES 值750以上から900未満までを[Critical]、ES值900以 上から1,000までを[Catastrophic］とする負荷ラン クに分類されている。

また、環境ストレス值と操船者の許容感との関係 はストレス值750を限界として750以上は「許容不可 能小750未満は「許容可能」な状態にあるという対 応が付いている。

ただし、本研究では、船の出会い状況の変化が当 該水域を航行する船の操船者に課す困難性を比較評 価することを目的としているので、交通環境ストレ ス（ $\mathrm{ES}_{\mathrm{s}}$ ) のみを評価のものさしとして用いた。

\section{2 避航のないシミュレーションの実施}

ここでの海上交通シミュレーションにおいては、 避航を考慮しないシミュレーションを実施した。こ のシミュレーション結果に対し環境ストレスモデル を適用すると、いわゆる潜在環境負荷(5) が求まり、 ここで評価対象とする 4 つの入出港方式においてそ れぞれぞれほぞの航行上の困難性が潜在的に課され るかが評価できる。このようにして求まる潜在環境 負荷の値の大きさは、避航操船の必要性の大きさを 示唆するものと考えてよい。

\section{3 評価対象船舶}

評価のものさしをあてる評価対象船舶（自船）は、 全長 $235 \mathrm{~m}$ の大型船とした。自船は、2.2節で説明し た交通流の下で【時計回り一方通航】また【反時計 回り一方通航】より直交バースに着離岸し、【右舷 付け一方通航】または【左舷付け一方通航】により 平行バースに着離岸する。

評価対象船舶としての自船は、Fig. 1 にみられる ように決められたルート上を航走するものとし、入 出港時の速力逓減、速力聥増については、いずれも 標準的な減速または增速パターンを設定した(6)。

また、自船の発生時間間隔は30分間隔とし、自船 同士の干渉を避けるとともに、それぞれの自船はそ れぞれ異なる交通流の中を航行するようにした。な お、自船の発生回数は合計72回とした。

\section{4 評価対象海域}

評価に際しては、入出港する自船と航路内を航行 する他船交通流との出会い状況が評価対象となるた め、Fig. 1 に示すような破線で囲まれた 6 力所の範 囲を評価対象海域とした。 


\section{4，入出港方式と交通環境負荷}

自船が評価対象海域を通航する間、自船に時々 刻々課される交通環境ストレス ( $\mathrm{ES}_{\mathrm{S}}$ 值)を計算し、 この時系列データをもとに、評価対象海域内で操船 者にとって許容できない負荷、すなわち、交通環境 ストレス值750以上が課された時間の割合を求めた。

Fig. 2 は、【時計回り一方通航】と【反時計回り一 方通航】について、合計72回の自船試行航行の間に 課された交通環境ストレスの、各負荷ランクの出現 割合を示したものである。Fig. 2 には、交通量を 1 時間あたり 9 隻、13.5隻、18隻とパラメトリックに 変化させたときの結果を取りまとめている。

いずれの交通量の場合も【反時計回り一方通航】 の場合よりも【時計回り一方通航】の方が入出港時 に操船者に課される負荷は小さい。

Fig. 3 は、【右舷付け一方通航】と【左舷付け一方 通航】について、合計72回の自船試行航行の間に課 された交通環境ストレスの、各負荷ランクの出現割 合を示したものである。この場合も同様に、交通量 を 1 時間あたり 9 隻、13.5隻、18隻とパラメトリッ

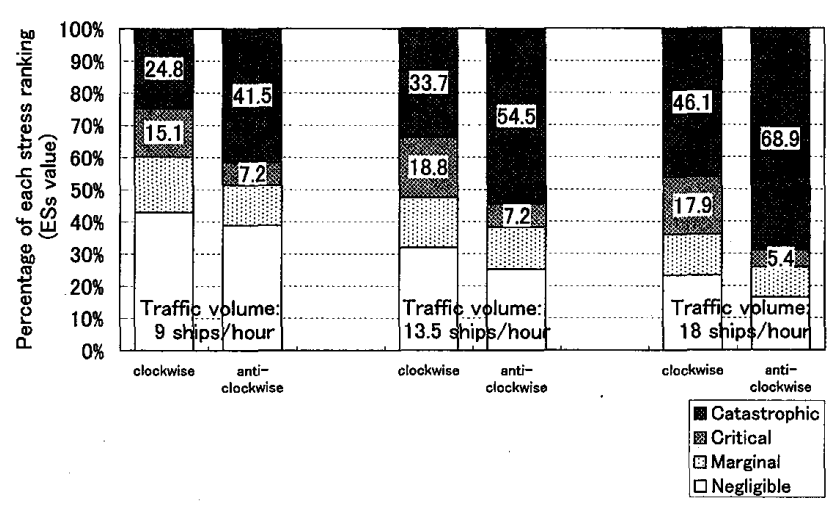

Fig. 2. Percentage of stress ranking in "Oneway (clockwise \& anticlockwise)"

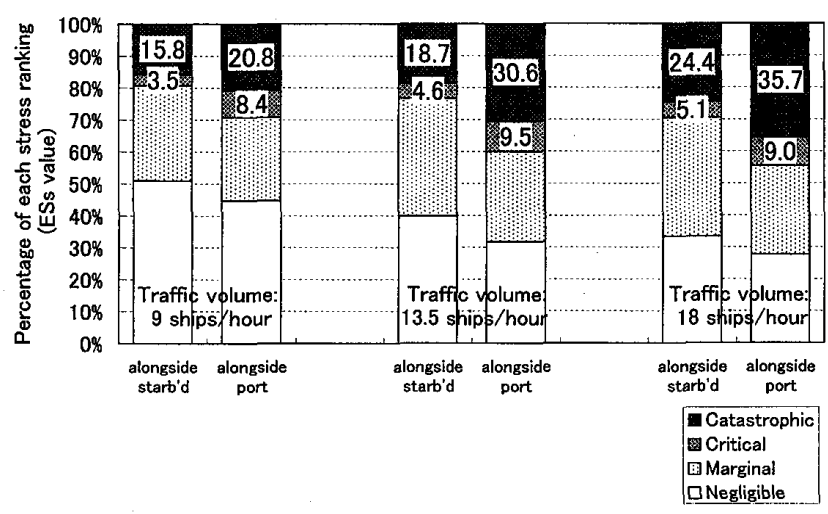

Fig. 3. Percentage of stress ranking in "Oneway (alongside starb'd \& port)"
クに変化させたときの結果を取りまとめている。

いずれの交通量の場合も【左舷付け一方通航】の 場合よりも【右舷付け一方通航】の方が入出港時に 操船者に課される負荷は小さい。

以上のことより、航路筋に直交して配置された直 交バースに着離岸する一方通航方式では、入出港時 に航路航行船舶の流れを横切る必要がなく、入港航 路からスムーズに離脱、そして、出港航路にスムー ズに合流できる【時計回り一方通航】方式が望まし い入出港方式であるといえる。

また、航路筋に沿って平行に配置された平行バー スに着離岸する一方通航方式では、やはり同じ理由 から【右䑪付け一方通航】方式が望ましい入出港方 式であるといえる。

\section{5.一方通航型港湾における限界交通量}

\section{1 時系列にみた交通環境負荷}

一方通航型港湾においては、直交バースへは【時 計回り一方通航】、平行バースへは【右舷付け一方通 航】が望ましい入出港方式であることを数值指標を 用いて明らかにしたが、ここでは、この2つの入出 港方式について、自船が大港航路から離脱、また、 出港航路に合流する過程で、どの場所でどの程度の 交通環境負荷が課されるのかを交通環境ストレス値 の時系列データをもとに調べてみた。

Fig. 4 (a)，(b)は、【時計回り一方通航】の入港着 岸時および離岸出港時に操船者に課される交通環境 ストレス值の時系列データを示している。このデー 夕は、評価対象船舶の72回入出港に伴う交通環境又 トレス値の時系列平均值を計算して求めたものであ る。

この図からは、入港着岸時は航路航行中が最も負 荷が大きく、右折して航路を離脱するに伴い負荷は 徐々に減少していくことが分かる。一方、離岸出港 時は航路合流前から合流し終えるまでの間に負荷の ピークがあることが分かる。なお、ここに、時系列 データが波打っているのは、各変針点で自船が針路 を瞬時に変えることに因るものである。

Fig. 5 (a)，（b)は、【右舷付け一方通航】の入港着 岸時および離岸出港時の時系列デー夕を示してい る。この場合も入港着岸時は航路航行中が最も負荷 が大きく、離岸出港時は航路合流前から合流し終え るまでの間に傎荷のピークがある。

これらの変化傾向は、いずれの交通量の場合にも 共通してみられるものであるが、しかし、交通量が 異なると交通環境ストレス值のピークの大きさには 違いがみられる。 


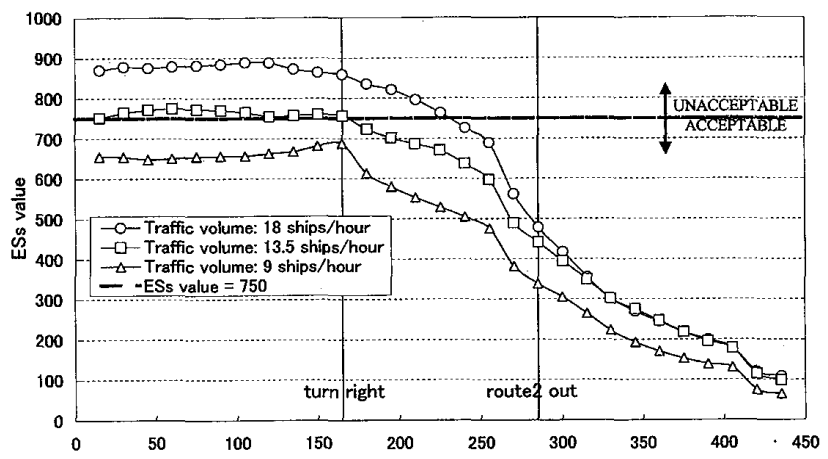

Fig. 4(a). ESs value in time series of "One-way (clockwise, in)"

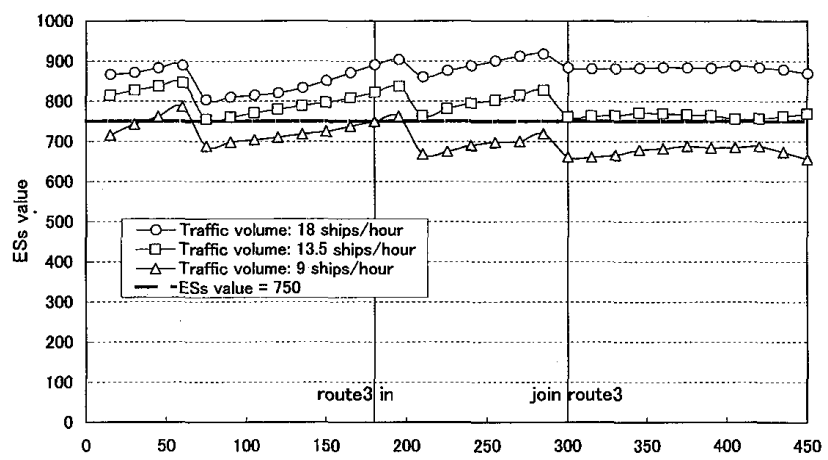

Fig. 4(b). ESs value in time series of "One-way (clockwise, out)"

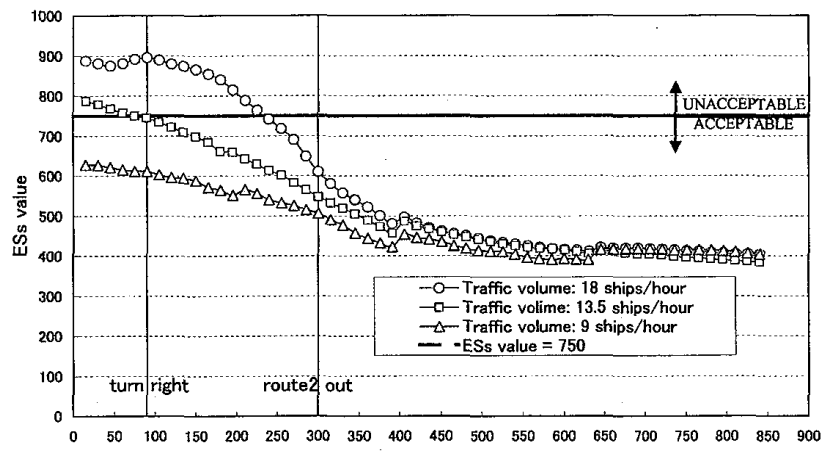

Fig. 5(a). ESs value in time series of "One-way (alongside starb'd, in)"

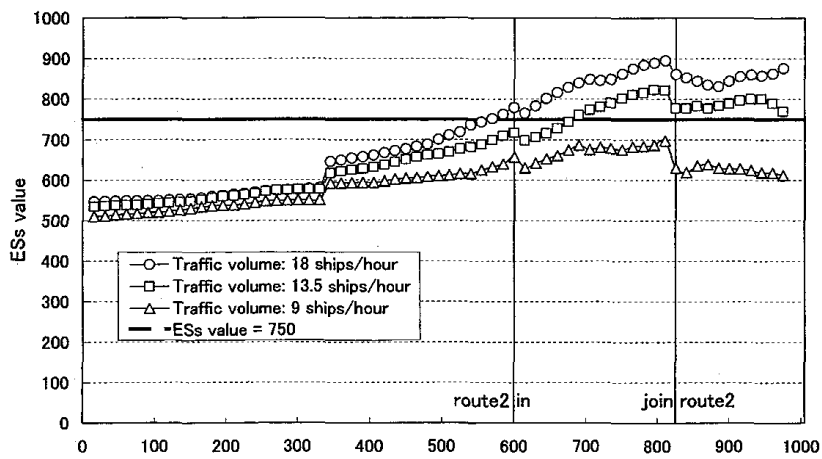

Fig. 5(b). ESs value in time series of "One-way (alongside starb'd, out)"
ここに、【時計回り一方通航】と【右舷付け一方通 航】の入出港方式において、交通環境ストレス值が 困難性の許容基準750を超えない限界の交通量に着 目すると、その限界交通量は、それぞれ、【時計回り 一方通航】では 8.5 隻/時、【右舷付け一方通航】では 10.5隻/時であることがわかった。

\subsection{L換算交通量による限界交通量の基準化}

「一方通航型港湾に大出港する船の操船者にとっ て、入出港操船過程において課される航行困難性を 許容範囲内とするためには、航路における他船交通 量を一定以下にすることが必要である」との観点に 立ってその限界交通量を求めてみると、【時計回り一 方通航】では 8.5 隻/時、【右舷付け一方通航】では 10.5 隻/時であった。

しかし、この結果は、先に条件設定したように、 大型船 $10 \%$ 、中型船 $10 \%$ 、小型船 $80 \%$ の船型構成比 率のもとで求められたものである。

そこで、新たに、自船として全長 $50 \mathrm{~m} 、 150 \mathrm{~m} 、 250$ $\mathrm{m} 、 350 \mathrm{~m}$ の船を設定し、船型構成比率も、さらに広 範囲の混合割合にも適応可能かどうかを確認するた め、小型船と中型船と大型船の隻数混合割合を $80 \%: 10 \% ： 10 \%$ の他に、50\%：40\%：10\%の場合、 および、30\%:30\%：40\%の場合についても対象に して、【時計回り一方通航】と【右舷付け一方通航】 の入出港方式における限界交通量を求めた。

Fig. 6 は、【時計回り一方通航】において操船者に 課される航行困難性を許容範囲内とするために必要 な他船交通量の限界を、標準船の長さを $40 \mathrm{~m}$ とする L換算交通量で基準化してプロットしたものであ る。また、Fig. 7 は、【右舷付け一方通航】の場合の 結果を示している。

これらの図をみてわかるように、【時計回り一方通 航】の場合も【右舷付け一方通航】の場合も、いず れも出港時における航行困難性が限界交通量を左右 することが明らかである。また、これらの結果は、 異なる船型構成比率に対しても L換算交通量のもと で基準化できることが分かった。つまり、このよj にして得られた限界交通量は、広い範囲の船型構成 比率、広い範囲の自船船型に対し有効な目安を与之 るものと理解できる。

\section{3 一方通航型港湾における限界交通量の目安}

一方通航型港湾において、【時計回り一方通航】と 【右舷付け一方通航】により入出港する際、その船 舶にとって交通環境ストレス值が許容基準750を超 えないような限界交通量を推定する近似式を、Fig. 6 およびFig. 7 に示したプロットデータをもとに求 めた。 


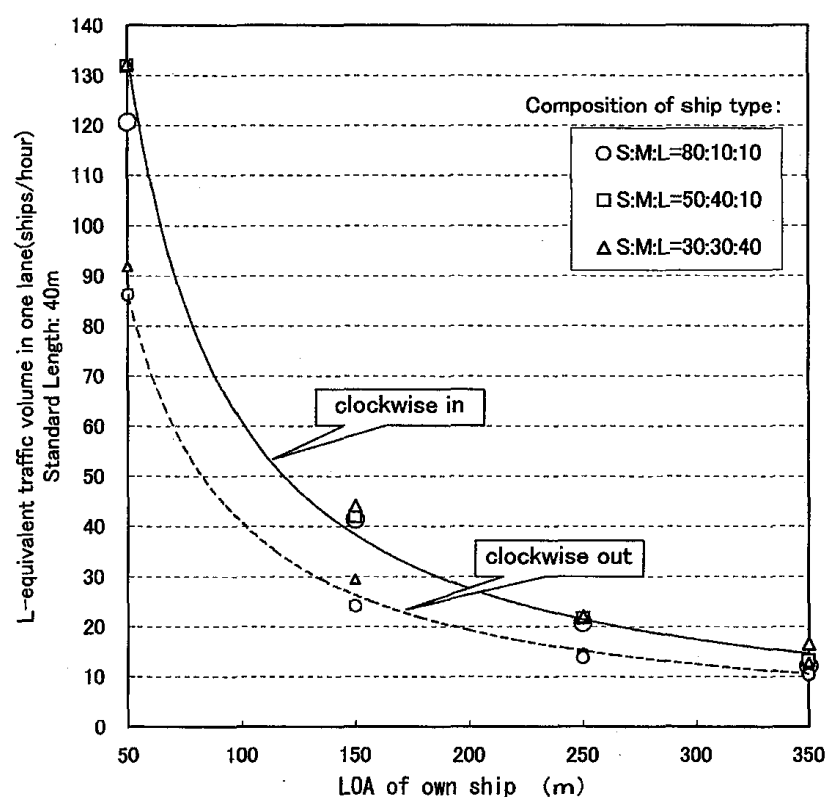

Fig. 6. The maximum allowable traffic volume when the ESs value is acceptable in "One -way (clockwise)"

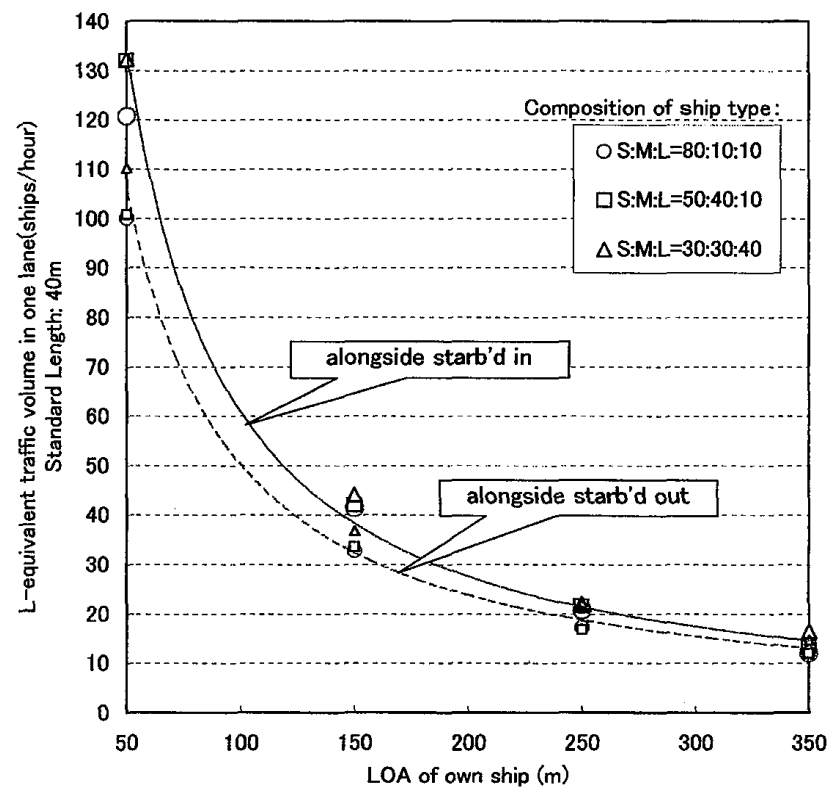

Fig. 7. The maximum allowable traffic volume when the ESs value is acceptable in "One -way (alongside starb'd)"

Fig. 8 にその結果を示し、近似推定式を以下に示 す。

【時計回り一方通航：出港時】

$$
Q_{L}=4,000 / L_{O A}
$$

【右舷付け一方通航：出港時】

$$
Q_{L}=5,000 / L_{O A}
$$

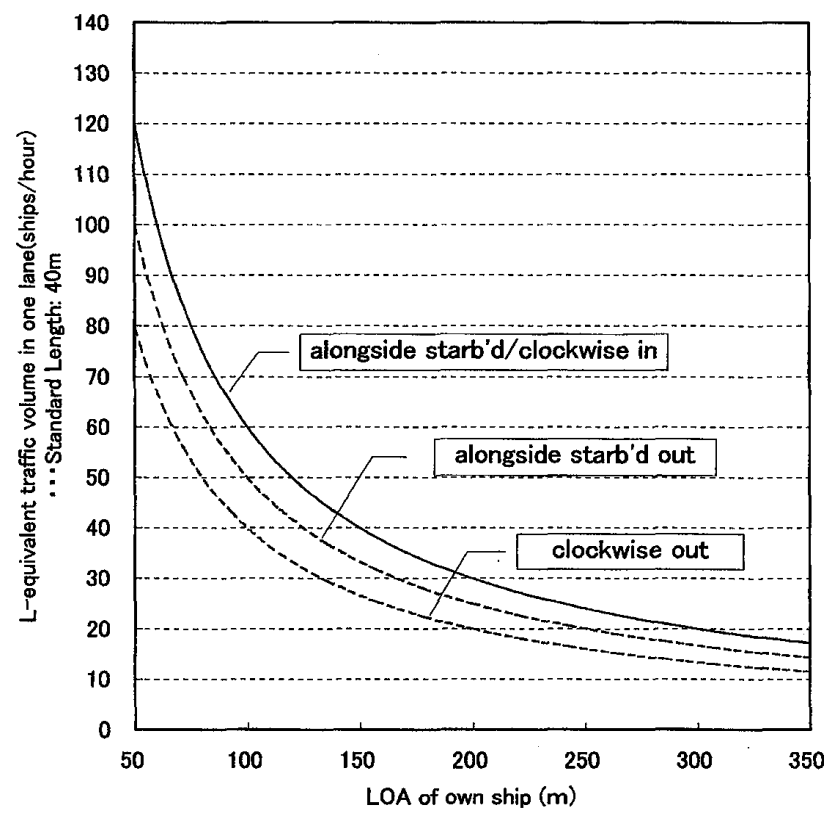

Fig. 8. The maximum allowable traffic volume when the ESs value is acceptable in oneway through port

【時計回り一方通航/右舷付け一方通航：入港時】

$$
Q_{L}=6,000 / L_{O A}
$$

ただし、 $Q_{L}: L$ 換算交通量(隻/時、標準船長 $40 \mathrm{~m}$ ) $L_{O A}:$ 自船の全長 $(\mathrm{m})$

式(1)，(2)，(3)により、一方通航型港湾を設計す るとき、対象とする最大船型の船舶の操船者が負荷 を感じることなく入出港できる限界交通量の目安を 求めることができる。また、現状の航路におけるL 換算交通量が与えられた時、一方通航で入出港する 船の操船者に課される困難性を許容範囲内にするた めの最大船型を求めることもできる。

さらに、Fig. 8をみてわかるように、【時計回り一 方通航】より【右舷付け一方通航】の入出港方式の 方がより多くの他船交通量が許容される状沉にあ る。このことは、同じ航路交通流条件の下で、操船 者に課される負荷は【時計回り一方通航】よりも【右 舷付け一方通航】の方が小さく、一方通航方式とし ては【右舫付け一方通航】の方が交通環境負荷軽減 の面からは有利であるといえる。

\section{6. むすび}

本研究では、一方通航型港湾における航路航行船 舶と着離岸船舶とのルート交錯の問題をとりあげ、 海上交通流シミュレーションを導入して交通環境負 荷軽減の観点から、一方通航型港湾における望まし い入出港方式について検討を行った。 
なおこの検討にあたっては、航行ルート上での 他船との出会いやルート交錯に伴う航行困難性を比 較評価するためのものさしとして、環境ストレスモ デルを適用し交通環境ストレス $\left(\mathrm{ES}_{\mathrm{S}}\right)$ を評価指標に 用いた。

以下にこの研究を通じて得られた主な知見をとり まとめる。

（1）一方通航型港湾においては、直交バースへは 【時計回り一方通航】、平行バースへは【右舷 付け一方通航】が望ましい大出港方式である ことを数值指標を用いて明らかにした。

（2）【時計回り一方通航】より【右舷付け一方通航】 の大出港方式の方がより多くの他船交通量が 許容されることより、一方通航方式としては 【右䑪付け一方通航】の方が有利であるとい える。

（3） 入出港操船過程において操船者に課される航 行困難性を許容範囲内とするために必要な他 船交通量の限界を求めた。その結果、【時計回 り一方通航】の場合も【右舷付け一方通航】 の場合も、いずれも出港時における航行困難 性が限界交通量を左右することが分かった。

（4）一方通航型港湾において、【時計回り一方通 航】と【右舷付け一方通航】方式により大出 港する際、交通環境ストレス值が許容基準750 を超えないような限界交通量を推定する近似 式を得な。

以上の結果は、一方通航型港湾における航路と バースの配䈯設計、一方通航により入出港する対象 船型の選定、周辺航路における他船交通量の管理、 等々一方通航型港湾を具体的に設計・管理・運用す る上での指針を与えている。

\section{参 考 文 献}

（1）井上欣三・胡 志武：操縦負荷軽減の観点から みた一力通航型港湾の検討, 日本航海学会論文 集，第107号，pp. 161-168，平成14年10月.

（2）日本海難防止協会：入出港等航行援助業務に関 する調査，pp. 192-195，平成10年 3 月.

（3）井上欣三：直線航路における航跡分布のモデル 化と航路分離に関する一考察, 日本航海学会論 文集，第58号，pp.103-115，1977年.

（4）并上欣三・増田憲司・世良 亘：海上交通安全 評価のための技術的がイドライン策定に関する 研究一I 。一環境負荷の概念に基づく操船の困
難性評価一, 日本航海学会論文集, 第98号, pp. 225-234, 平成 10 年 3 月.

（5）井上欣三他：海上交通安全評価のための技術的 ガイドライン策定に関する研究一III. 一困難性 評洒とヒューマンファクター一, 日本航海学会 論文集，第100号，pp. 191-198，平成11年 3 月.

（6）日本海難防止協会：入出港等航行援助業務に関 する調查，pp. 216-221，平成10年 3 月.

\section{質 疑 応 答}

長澤 明 (海上保安大学校) : 平行交通流からの分 離、交差、合流の有無が限界交通量の推定に影響 するものと思われますが、平行交通流の間隔など 交通量以外に設定された交通環境要素をパラメト リックに変えて検討された例があればお教えくだ さい。

胡 志武：この研究では、水路幅が限られた港内航 路を想定し、中央線がブイで表示される時の航跡 分布モデルに基づいて、航路交通流の発生条件を 設定しました。ここでは、狭水路の上うな広い航 路を想定していませんので、平行交通流の間隔を 変えてはいません。なお、平行交通流の間隔によ る交通環境負荷の変化については、朴榮守氏の「海 上交通管理に関玄る基礎的研究」(神戸商船大学博 土論文、2002年 1 月、pp.93-100)を参照してくだ 巳い。

中村紳也 (日本海洋科学)：一方通航型港湾のメリッ トがよく解りました。興味深い講演ありがとうご ざいます。限界交通量をESs值を用いて求放れ た時、他船舶の発生状況（等時間間隔orポアソン 分布……) 発生場所等の要素が結果 (限界交通量) に及ぼす影響はどの程度でしょうか。

胡 志武：今回は他船舶の発生時間間隔はポアソン 分布に従い、発生場所は設定した航路に設けた ゲートラインにおいて正規分布するものとしまし た。ただし、一般的に、港内航路のような水路幅 が比較的狭いときは、他船舶の発生時間間隔は等 時間間隔であれポアソン分布であれ、他船舶の発 生場所は一様分布であれ正規分布であれ交通環境 負荷はさほど差は見られません。詳細は朴榮守氏 の「海上交通管理に関する基礎的研究」（神戸商船 大学博士論文、2002年 1 月、pp. 74-91）をご参照 ください。従いまして、他船舶の発生状況、発生 場所等の要素が結果（限界交通量）に及ぼす影響 はさほど大きくないと考えられます。 